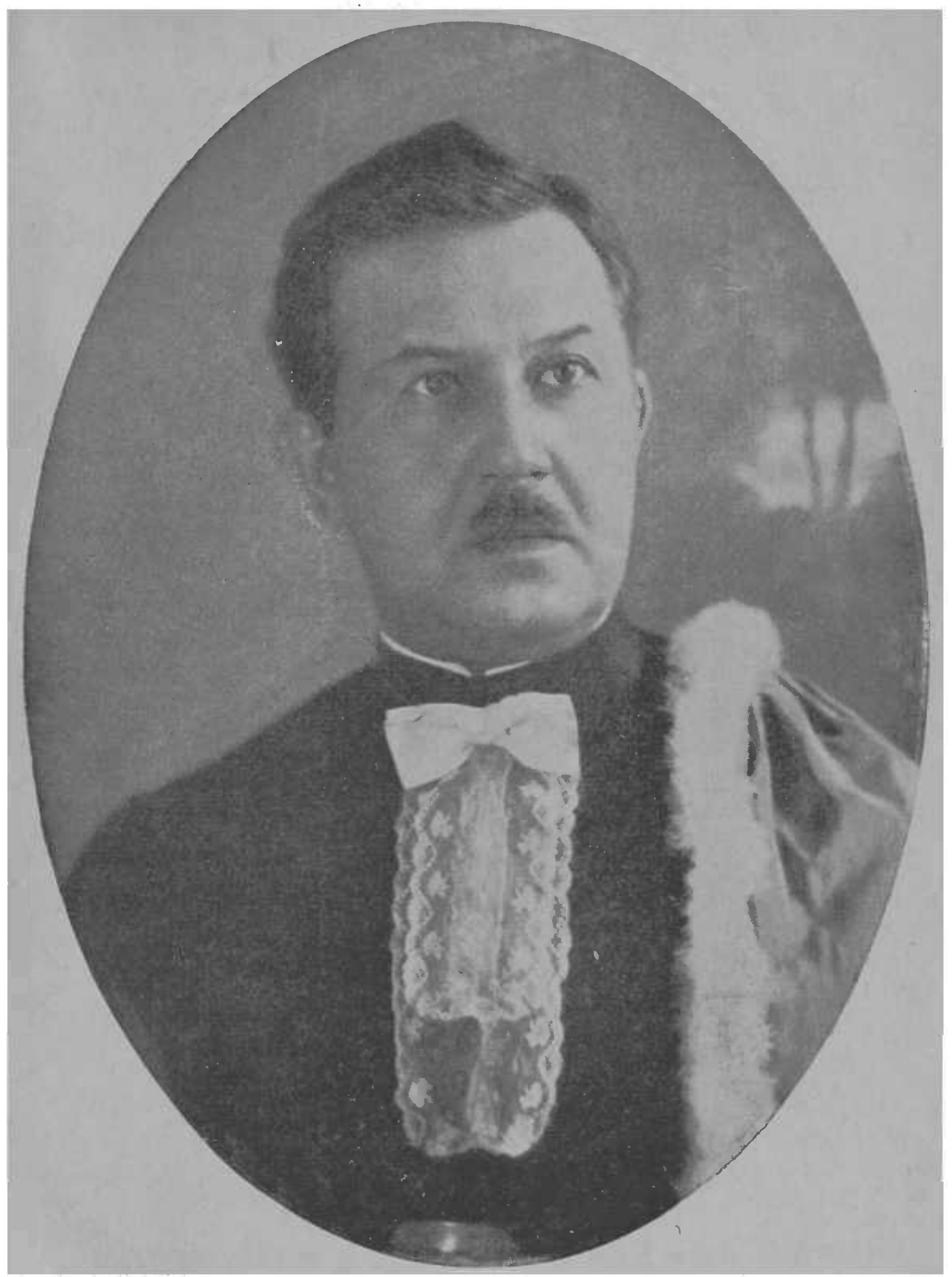

PROF. RUBIÃO MEIRA

Magnifico Reitor da Universidade de São Paulo 


\section{A "Revista de Medicina" nas palavras do Professor Rubião Meira, Magnifico Reitor da Universidade de São Paulo}

A "Revista de Medicina", orgão do Centro Acadêmico "Oswaldo Cruz", que vem sendo publicada ha anos, merece ser considerada como produto de esforço e trabalho de um grupo de moços, que honram a Faculdade de Medicina da Universidade de São Paulo.

Tendo aparecido ha muito tempo, nunca teve o desenvolvimento que agora apresenta de um ano para cá, em que os seus numeros têm vindo a luz com grande regularidade e cheios de artigos apreciaveis.

Representando o pensamento da mocidade estur diosa da Faculdade de Medicina, patentéia o valor da aprendizagem ali recebida e merece a "Revista de Medicina", o apoio de todos que desejam levantar o nivel de nossa cultura.

Nã́o são sómente os acadêmicos que, contribuem, com seus trabalhos, para o aparecimento da Revista, mas tambem inumeros prafessorés que colaboram com assiduidade, realçando destarte, o valor desse repositorio de estudos.

$A$ atual aprésentação da "Revista de Medicina" merece aplausos pela substancia e pela maneira com que está sendo feita, cabendo incentivá-la para que continue a patentear $b$ merẹcimento da classe de estudantes.

E o que faço, dando publicamente o meu modo de pensar, que certó representa a expressão da verdade, esperando que todos contribuam para o desenvolvimento sempre crescente dessa bella Revista.

Falo com ânimo desprevenido, e só com o intuito de bater palmas a valores.

(a) Prof. RUBIÃo MEIRA 